Article

\title{
On-Drawing South American Extent: Geo-Poetic Mapping Palimpsest in the Travesías de Amereida
}

\author{
Álvaro Mercado ${ }^{1,2, *}$ and Geoffrey Grulois ${ }^{1}$ \\ ${ }^{1}$ LoUlsE-Laboratory on Landscape, Urbanism, Infrastructures and Ecologies, Faculty of Architecture La Cambre Horta, \\ Université libre de Bruxelles, 1050 Brussels, Belgium; E-Mails: alvaro.mercado.jara@ulb.be (A.M.), \\ geoffrey.grulois@ulb.be (G.G.) \\ ${ }^{2}$ School of Architecture and Design, Pontificia Universidad Católica de Valparaíso, 2580129 Valparaiso, Chile \\ * Corresponding author
}

Submitted: 14 January 2020 | Accepted: 14 April 2020 | Published: 30 June 2020

\begin{abstract}
Contemporary urbanization, as a process extended beyond the cities, requires original design practices to contribute to the critical understanding and visualization of the multiple spatial and temporal layers that shape the territories. In this account, this article examines the geo-poetic mapping developed by the Valparaiso School of Architecture, as a radical means of exploring the territories and elaborating their palimpsestic representations. This contribution unfolds the geopoetic vision of the South American continent created in the sixties by the School of Valparaiso, in Chile, as fundamental groundwork to critically question the historic and ongoing urban occupation of territories and their representations following colonization. Besides, it presents the Travesías de Amereida, a collective and situated architectural study performed throughout the vast South American inland, as a unique geo-poetic practice in which freehand mapping becomes an original means of rethinking and redrawing the ever-changing American extent. Through the analysis of drawings made before, during, and after the travesías were undertaken between 1965 and 1985, this article outlines how the geo-poetic vision and mapping practices - that embodies iterative freehand drawings combining different temporality, spatiality, and situated experiences-have attempted to unveil the South American continent as a palimpsest: an open extent to trace the ever-changing footprints that reshape its content. To conclude, the article assesses the contribution of situated geo-poetic mapping as a critical design practice to study and visualize the ever-changing, multi-layered, and multi scalar-realities on virtually unknown territories of contemporary urbanization.
\end{abstract}

\section{Keywords}

geo-poetic mapping; palimpsest; situated practice; South American extent; urbanization

\section{Issue}

This article is part of the issue "Territories in Time: Mapping Palimpsest Horizons" edited by Chiara Cavalieri (UCLouvain, Belgium) and Elena Cogato Lanza (EPFL, Switzerland).

(C) 2020 by the authors; licensee Cogitatio (Lisbon, Portugal). This article is licensed under a Creative Commons Attribution 4.0 International License (CC BY).

\section{Introduction}

In recent decades, the urbanization process has become a global and fast-growing phenomenon, expressed in the multiplication of the urban population over the last 60 years, and reinforced by the estimation that by 2050 at least 66 percent of the world's population will live in cities or urban agglomerations that need to be studied and planned (UN-Habitat, 2016). However, an emergent understanding of contemporary urbanization as a process extended beyond the conventional cities and the hinterland boundaries has contributed to the territories being visualized as places where deep, but virtually unknown environmental and socio-cultural transformations are the result of the current local/global interdependencies driven by global capitalism (Brenner, 2016; Correa, 2016).

In effect, the contemporary process of urbanization (Brenner, 2014; Kaika \& Swyngedouw, 2014) is re-shaping 
the notion of territories towards multi-scale geographies, situations, and differences (Elden, 2013; Escobar, 2008; Raffestin, 2012; Santos, 2017). These new notions challenge the conventional binary means of reading urban and rural interactions, the geopolitical boundaries of countries and regions, and they call for new tools to read and represent the ever-changing territorial diversity.

This understanding of urbanization has provoked a territorial revival in architecture and urbanism to explore new critical design-practices and epistemologies as a way to overcome the conventional and dominant technocratic approaches to urban-planning (Bélanger, 2017; Correa, 2016; Ibañez \& Katsikis, 2014; Waldheim, 2016). In this context, situated mapping (Corner, 2014; Havik, 2014; Viganò, 2014, 2016) has become a key practice to represent, analyze, and interpret territorial complexities because it investigates the spatial dimension between large-scale geographies and local situations, and in the temporal dimension between the many layers of historical milestones that have shaped the territory as a palimpsest (Corboz, 1983).

\subsection{Case Study: The Travesías de Amereida}

Regarding the contemporary process of urbanization beyond the conventional city's boundaries and facing the need for situated design practices to analyze and interpret the multiple spatial and temporal layers shaping territories, this article deploys the practices of the School Architecture and Design of Valparaiso (Pontificia Universidad Católica de Valparaíso) in Chile. The School of Valparaiso presents a radical approach to reading the historiography which has become embedded in the area since colonization (O'Gorman, 1958/2010) and the current occupation of territories in South America. Through the invention of a geo-poetic vision of the extension Americana (American extent) created in the mid-sixties (Iommi et al., 1967, 1986) and continuing until today, the School of Valparaiso has developed the practice of the travesías de Amereida-collective and situated architectural studies performed mainly beyond the large cities located on the edges of the continent-which use situated mapping and design practices to radically explore, rethink, and redraw the American extent.

This contribution analyses archive documents, mainly drawings made before, during, and after the first travesías performed by the School of Valparaiso between 1965 and 1985. It traces the emergence of the geo-poetic vision of Amereida and its notion of extent-instead of territory-as a means of facing the geographical space of the South American continent without frontiers or preconceived definitions. Then, it investigates how this notion has been fundamental for the geo-poetic mapping developed in the travesias, which we envisage as an attempt to unveil the continent's territorial transformation as a palimpsest. Besides, the article unfolds the particularities of this geo-poetic mapping palimpsest, which are embodied in iterative drawings which com- bine different temporality, spatiality, and situated experiences. Finally, the article aims to show that situated geo-poetic mapping provides an important contribution to the discussion of how to represent the everchanging, multi-layered, and multi-scalar realities within virtually invisible territories that experience contemporary urbanization.

\section{Towards a Geo-poetic Mapping of South America}

In the mid-1960s and after a decade of leading a school of architecture which linked architecture to poetry (Escuela de Arquitectura UCV, 1972), the poet and professor Godofredo lommi echoed the traces of historical dwellings imprinted on the continent by asking this radical question: What is the origin and the present meaning of 'being American'? (Iommi, 1999). This triggered the realization of the first travesía in 1965 and lead to the invention of a geo-poetic vision of the continent which was subsequently embedded in the way of conceiving, studying, and practicing architecture within the School of Valparaiso. Thus, this geo-poetic vision allowed the School to expand its situated modes of learning architecture beyond the classroom (A. Cruz, 1959) towards the continent.

In 1965, the professors of the School of Valparaiso together with artists and philosophers, organized a trip throughout the interior lands of South America that they called travesía, an experience oriented to poetically "unveil" (lommi et al., 1967, p. 26) the continental realities of territories far from the cities (see Figure 1). For them, the big cities tended to hide the original meaning of being American, because "they are dense of knowledge and splendid but empty of myth, inventing themselves quickly and fallaciously" (lommi, 1983, p. 2).

The travesía was integrated by the Chilean architects Alberto Cruz and Fabio Cruz, the Argentinean sculptor Claudio Girola, the Argentinean poet Godofredo lommi, the Panamanian poet Edison Simons, the English poet Jonathan Boulting, the French poet and philosopher Michel Deguy, the French designer Henry Tronquoy, the Argentinean painter Jorge Pérez Román, and the French philosopher François Fèdier. They began the geo-poetic experience and study (lommi et al., 1986, p. 159) on 31 July in the city of Punta Arenas, in the extreme south of Chile. Their trip went through the hinterland of the Argentinean Patagonia and pampas, passing through diverse landscapes and visiting small villages spread in the territorial extent. Due to the presence of the guerrillas in the Bolivian region of Tarija, this travesía ended suddenly on 13 September (Iommi et al., 1986, pp. 200-201).

Even if the sudden disruption of the trip made their goal to reach the Bolivian city of Santa Cruz de la Sierra impossible, the group experienced 42 days of poetic adventure, guided by openness towards the "unknown" encounter with the continent (lommi et al., 1986, p. 70). The openness embedded in the travesía arose from the aim to incarnate the modern metaphor of the unknown 


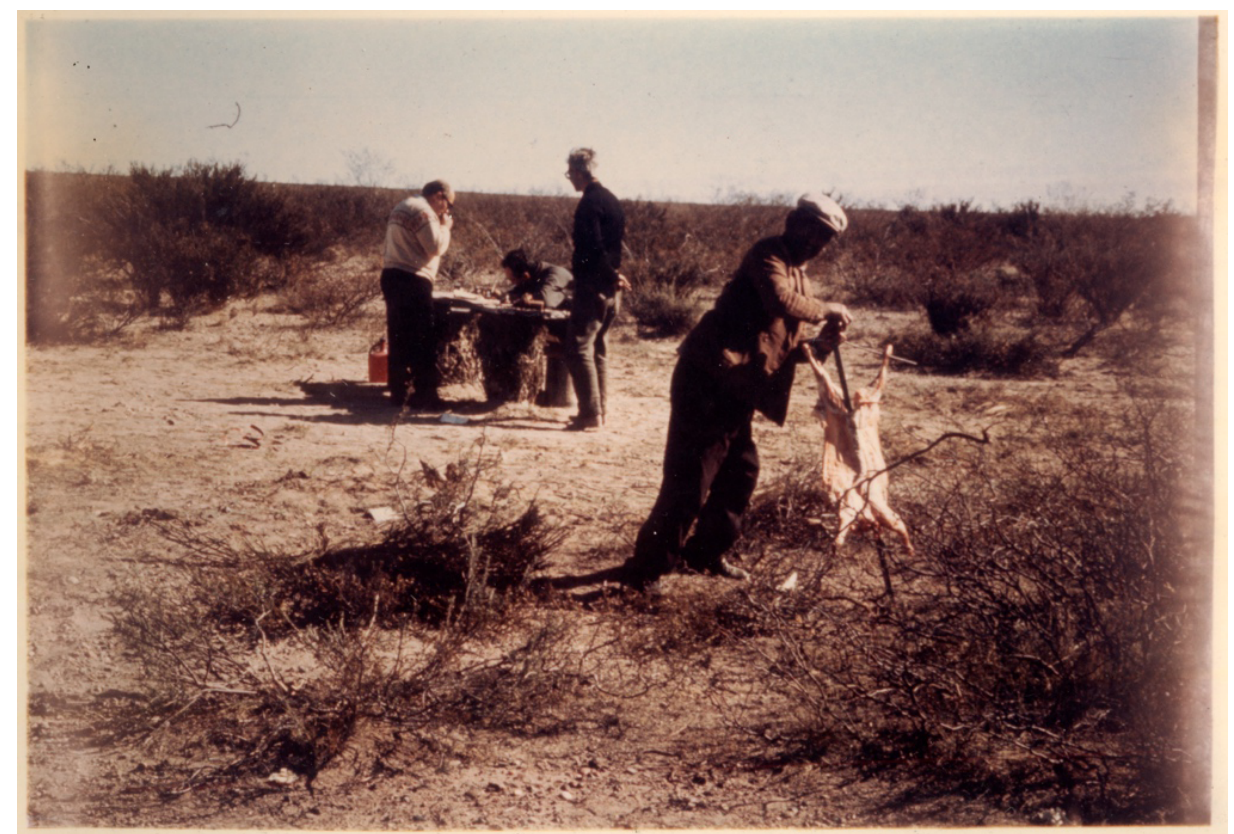

Figure 1. First travesía, 1965, with Alberto Cruz, Chilean architect, Godofredo lommi, Argentinean poet, Jorge Pérez Román, Argentinean painter, and a gaucho in the Argentinean Pampa. Source: Archivo Histórico José Vial Armstrong (1965). Reprinted with permission.

expressed in the poetry of Baudelaire and Rimbaud, which they explored in fortuitous encounters with reality through creative action (lommi, 1982b). This metaphor guided their inquiries into the meaning of being and inhabiting America, and lead them to engage in poetic acts, the construction of ephemeral works of art, discussions with local communities, and to carry out architectural observations in the territory. All these collective experiences were gathered in the creation of a geo-poetic vision of South America, called Amereida.

During the trip, the group collectively drafted the poem Amereida, a title that alluded to their reflections on the meaning of being American weaved with the invention of a founding myth based on Virgil's Aeneid (Iommi, 1982a, 1982c; lommi et al., 1967). The poem attempted to recreate the idea of latinidad in the Americas through a poetic that echoed the founding myth of the Greco-Roman culture represented in the wandering journey of Aeneas. Therefore, Amereida proposes a poetic understanding of latinidad, has the potential to trace back the meeting of multiple races, languages, and territories of the Americas (Iommi, Rodriguez, Emilfork, \& de Nordenflycht, 1972), and to overcome the geopolitical conceptualization developed since the 19th century, when the notion of latinidad was related to dominion and colonial hegemony.

The book, Amereida, published in 1967, is a poetic narration written by the group in their diverse languages. The poem was composed by historiographical viewpoints about the "invention of America" (O'Gorman, 1958/2010), interwoven with words coming from classical and modern poetry, with the direct observations and creative actions performed in the interior of the South
American continent. All these elements remain almost hidden within the poem which is written collectively in a non-linear chronology of the trip and without any formal references or quotations. Nevertheless, the poem presents ten cartographies (see Figure 2) that permit access to the geographical and territorial vision of the South American extent embedded in Amereida.

\subsection{Ten Maps of Amereida}

The ten maps in the Amereida represent the first transcription from the metaphorical space of the poem to the geographical space of the South American continent. By displaying a blanked continental extent (A. Cruz, 1995; lommi, 1965, 1982a) without any of the geopolitical divisions which traditionally portray sovereignty and control over territories, the vast continent is represented as a primary form shaped by nature by the bathymetry of the oceans (Figure 2[1]), by the great rivers connecting lands (Figure 2[5]), and by the mountains dividing regions (Figure 2[6]). Concomitantly, the extent as a blank footprint map does not seek to represent the terra nullius - the governable void drawn by the imaginary, mastery, and control used in European mapping during colonization (Ashcroft, Griffiths, \& Tiffin, 2013, p. 28)on the contrary, the extent represents the possibility to unveil the lands as a palimpsest: an open blackboard upon which the ever-changing footprints that reshape the continent can be traced.

Subsequently, the representation of the Interior Sea (Figure 2[3]) refers to the vast inner lands of the continent, an interior conquered but ignored, sparsely inhabited, and almost strange to most of the urban popula- 

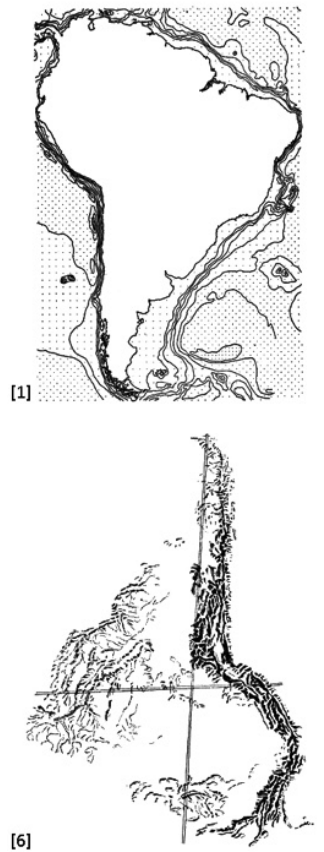

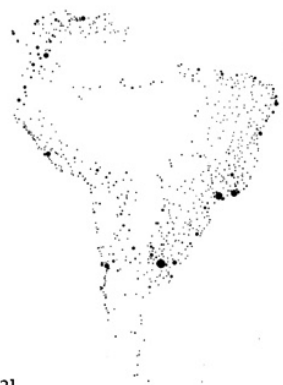

[2]

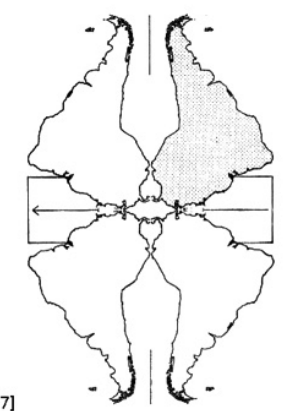

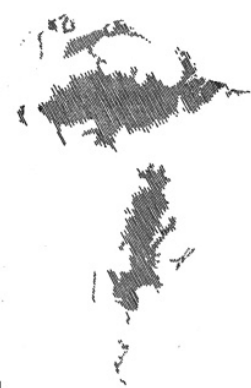

[3]

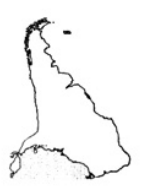

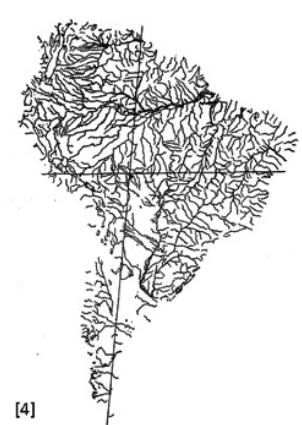
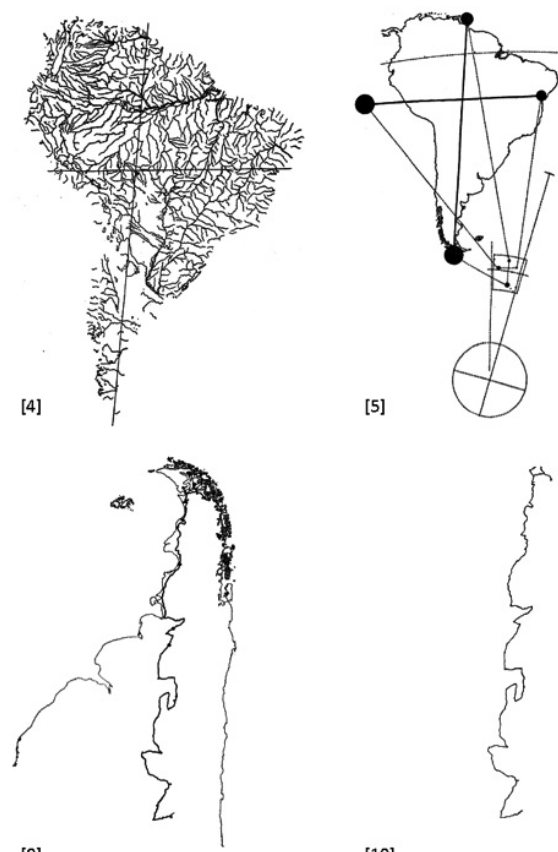

[9]

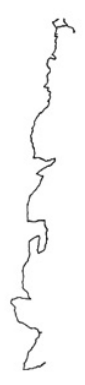

[10]

Figure 2. Maps from Amereida, 1967. Source: Iommi et al. (1967, pp. 9, 21, 29, 35, 39, 40, 171, 173, 186, 187). No Copyright.

tion occupying the edges of the continent (lommi et al., 1967, p. 18). Poetically, the Interior Sea is the unknown (Iommi, 1984), a land for voyage, such as those taken by Aeneas and by the travesía (Iommi, 1982a, 1983). This map, made by lines without a backdrop or perimeter, represents the vagueness of the Interior Sea, and its open shape is an inversion of the dots-map (Figure 2[2]). The dots-maps shows-as NASA's nighttime satellite images have since 2009 - the location of the big cities in the edges the continent.

Then, the radical action of rotating the map represents the notion of the Own North (Figures 2[6, 7, 8]), an operation aligned with the commonly used expression of 'to have a north,' which means to have an orientation or a goal. Thus, to conceive a proper orientation for the southern continent, to have a North is to look to the South (Eyquem, 1985; lommi et al., 1967). The map is turned and inscribed with the Southern Cross constellation over the chart (Figure 2[4]) as an action to overcome the traditional Cartesian axes in colonial cartographies and to open up the multiple orientations that emerge from this intersection (A. Cruz, n.d.).

Finally, the two maps made with the route of the travesía (Figures $2[9,10])$, followed by the final sentence of the book "el camino no es el camino" (the road is not the road; lommi et al., 1967, p. 189), represent the incarnated metaphor of the unknown as the constant equívoco (equivocation; lommi et al., 1986, p. 213). This means that the distance between what is known and what is to be known exceeds any plan and final purposes of a project, nevertheless, the openness towards the unknown allows one to encounter reality.

\subsection{The Travel-Log of Travesía}

The ten maps accompanying the poem Amereida are clearly not technical representations of the South American territory, but they do show the particular geopoetic notion of the School towards the continental extent (A. Cruz, n.d.), based in the reflection between historiographic temporality and incarnated spatiality. From an architectonic perspective, these maps are the groundwork for a new exploratory mapping practice which aims to trace the links between the crossed continent and the human scale, captured through the observación arquitectónica (architectural observation). This is a situated drawing practice, which consists on making of freehand drawings accompanied by short notes, through a slow process allows one to contemplate and grasp the spatiality, gestures, and acts which shape everyday life. For the school, the architectural observation implies a poetic process in the sense of poiesis, that seeks to reveal and eulogize the reality, and a creative act in which the observations nourish the architectural study (A. Cruz, 1959, 1982; F. Cruz, 1993).

This geo-poetic mapping exploration-traced in the situated drawing practices developed by the architects and designers of the School of Valparaiso-seems to have its origins in the realization of the architectural travel-log of the first travesía de Amereida in 1965 (see Figure 3). The travel-log made by the architect and professor Alberto Cruz (A. Cruz, 1965) illustrate this new mode of mapping where freehand drawings such as the architectural observations, schematic maps, brief texts, and plans, are deployed as a collage to describe and in- 


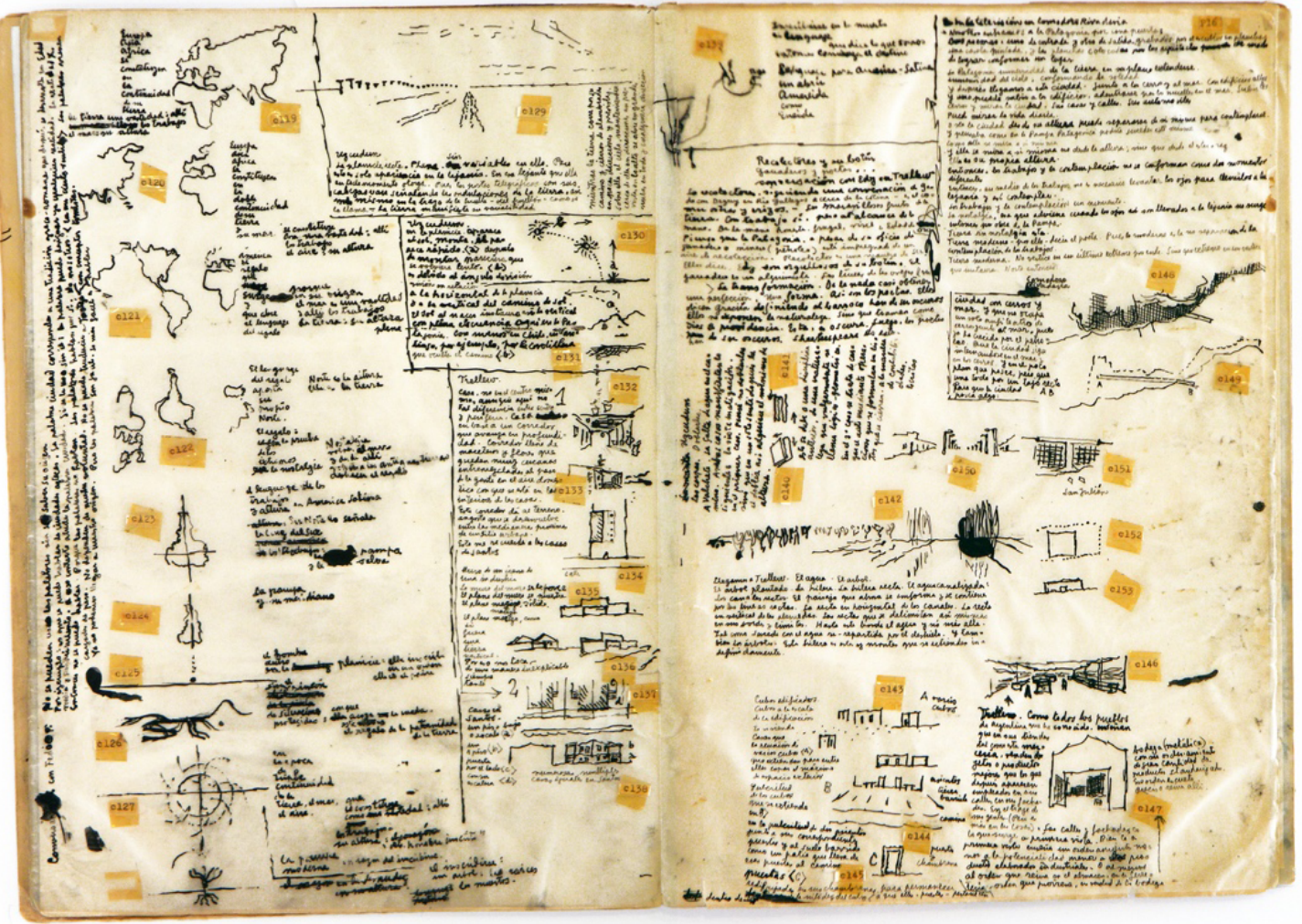

Figure 3. Travel-log of Alberto Cruz, Travesía de Amereida, 1965. Source: A. Cruz (1965). Reprinted with permission.

terpret the different territorial situations experienced on the trip.

In the pages of this travel-log it is possible to identify the original schemes of the continental rotation illustrated in Amereida, next to sketches and notes about the life in the vast pampas, and a series of observations of the landscape and buildings of the Patagonian villages of Uzcudum and Trelew (see Figure 3). In the same pages, a reflection on the South American Plazas Fundacionales with schematic plans and notes is followed by some statements describing the differences between creating towns and exploiting the territory. Architectural observations about the Argentinean villages of Santa Rosa, Dorotea, and Comodoro Rivadavia are mixed with the descriptions of some poetic acts performed during the trip.

The density of the content displayed in these mapping compositions can be understood as a palimpsest process because it brings together the diverse temporality and spatiality as experienced during the journey. It allows one to follow in their footsteps and the subtle historical traces imprinted on these South American territories which are normally omitted by conventional maps. Hence, these freehand drawings are different from those images captured by objective cartography or photography, because they seem to incorporate a variety of situations that move from two to three spatial dimensions, in different territorial scales, and different temporalities.

Furthermore, the travel-log that might be comparable to the ethnographer's notebook, did not only oper- ate as a descriptive-analytical tool, but also as a creativedesign tool to act and to make on the ground. In effect, the travel-log of Alberto Cruz is a set of large sheets folded to be carried during the trip. The 15 slides contain 321 drawings in aleatory order, creating a particular narrative composed by: (1) personal interpretations and architectural observation of landscapes, (2) the collective design of ephemeral works of art and poetic acts, (3) the encounter with the locals, and (4) the daily planning of the trip.

Consequently, the travel-log of Cruz and the book Amereida are two fundamental elements to understand the geo-poetic vision and the mapping practice developed during the travesía, in which poetry did not become only a metaphor of reality, but was conceived as an exploratory means to produce situated knowledge and to produce artwork beyond the conventional disciplinary boundaries of architecture and urbanism.

\subsection{Tesis del Mar Interior y del Propio Norte}

The poetic fundamentals which originated from the first travesía de Amereida became the groundwork for the architecture and design practices embedded within the School of Valparaiso. As such, the seminal works presenting their geo-poetic notion to the field of urbanism, La Tesis del Mar Interior (Thesis of the Interior Sea) and La Tesis del Propio Norte (Thesis of the Own North; Escuela de Arquitectura UCV, 1970), were both pre- 
sented at the First International Seminar of the Pacific, held in 1970 in Viña del Mar, Chile. This meeting focused on the debate surrounding geopolitical and economic strategies for the development of the central and peripheral countries of South America towards the Pacific Front. In this context, and as a way to incorporate alternative viewpoints regarding South American urban development beyond the conventional political-economic discussion, the School of Valparaiso presented both theses as poetic-scientific bases for the exploration of new analogies and distinctions between specific data and criteria encompassing history and geopolitics (Buttazoni et al., 1971).

The theses manuscripts were accompanied by 15 large-scale maps to represent their proposal. One of these maps displays all the colonial and commercial routes in the Pacific Front during the 16th and 17th centuries. This map purposefully set the Pacific Ocean at the center of the chart to question the cartographies produced since the 16th century, in which the Atlantic Front and Europe occupied the central space (see Figure 4). Another map shows an aerial view of a South American continent without borders or geopolitical frontiers, representing the Interior Sea as postulated in Amereida. In the map, the red dots indicate the cities surrounding the continent, and the dark lines crossing the chart signal the first conquest expeditions performed in the 15th and 16th century, together with the current transoceanic industrial flows through the inland of the continent (see Figure 5). In spite of their careful elaboration, the
15 maps did not aim to show a territorial development strategy for South America, on the contrary, they were a speculative means to present the notion of Interior Sea and the continental extent of the Americas. For the School, these notions were fundamental to their thinking of the continent, the Pacific Front, and the World System; such notions lead them to question urbanism based merely on the productivity of a country, of a continent or a region (Buttazoni et al., 1971).

All these maps were redrawn and presented in the exhibition "30 Años de la Escuela de Valparaíso" celebrated in 1982 at the National Museum of Fine Arts in Santiago de Chile, to publicly affirm a geo-poetic commitment towards the Americas. Following the exhibition, the School decided to incorporate the travesías as a pedagogical experience to unveil the American extent.

\section{On-Drawing Territories: The Iterative Mapping-Practice in the Travesías}

Since 1984, the travesías prolong the study of the urban towards the continent, carried out mainly in remote places outside the comfort of city life. The professor Alberto Cruz described the travesías as a study of the American continent that requires crossing through its mainland and its oceans (A. Cruz, 1995, p. 8), because for him, travelling is the way to recognize the magnitude of the continent and to identify the constellation of elements and places through which the continental extent is exhibited and ordered (A. Cruz, n.d., p. 2,3).

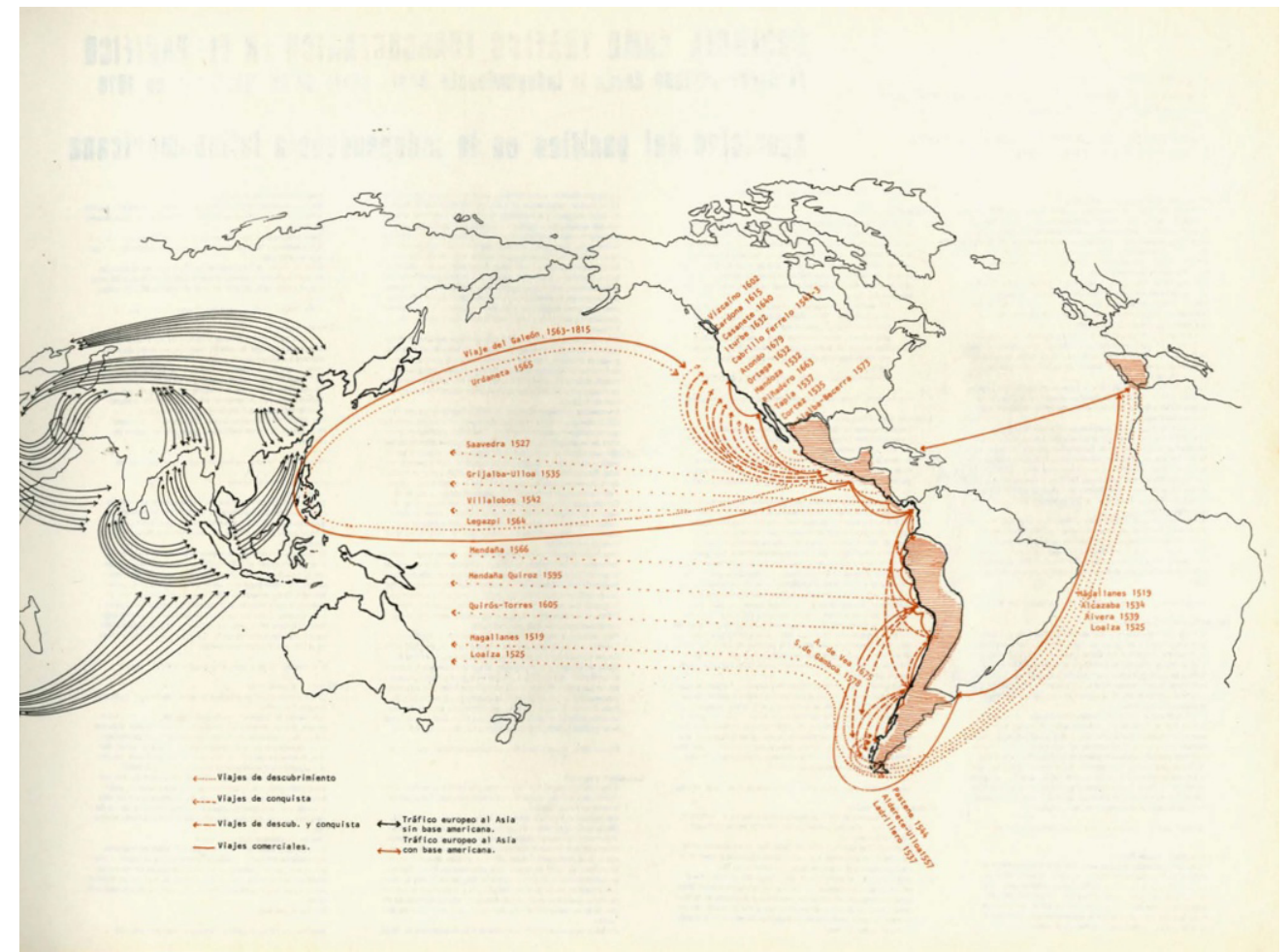

Figure 4. Map of nautical routes in the Pacific Ocean during the 16th and 17th century. Source: Buttazoni et al. (1971, p. 15). No Copyright. 


\section{COGITATIO}

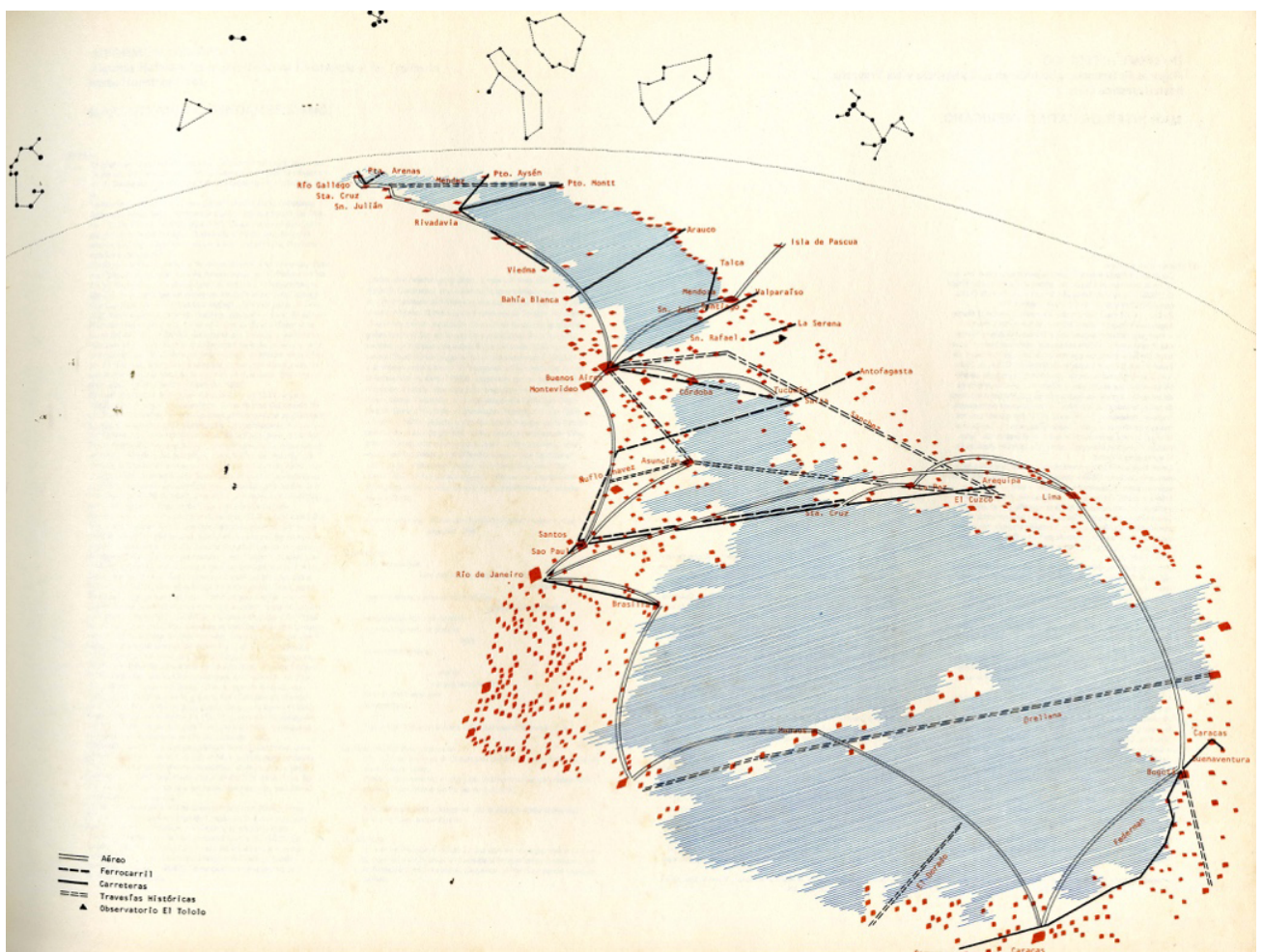

Figure 5. Map of the Interior Sea and South American cities. Source: Buttazoni et al. (1971, p. 29). No Copyright.

The travesías are trips performed every year by all the studios of the School of Valparaiso, in which of students and professors are engaged in a collective life, work and study (Escuela de Arquitectura UCV, 1996). This includes the organization of the trip, the permanence in the places of destination and, ultimately, the design and construction of an ephemeral Work of architecture whose purpose is to value the diverse situations recognized in the territory (see Figure 6).

In this way, the works of architecture erected in the travesías de Amereida are not conceived as projects to master the land or solve local problems (Jolly, 2017),

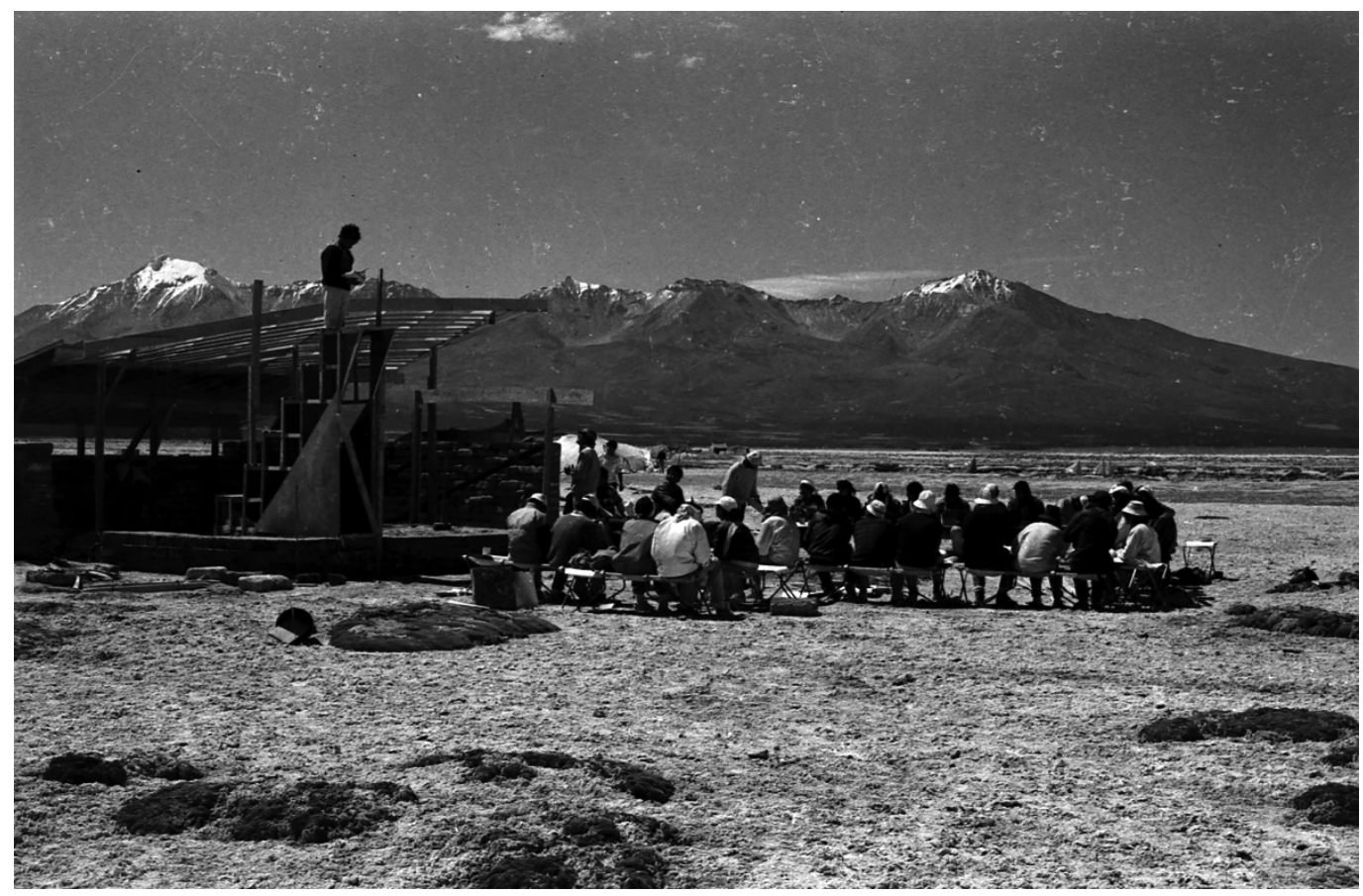

Figure 6. Travesía of Salar de Coipasa, 1987, Atacama desert, Bolivia. Source: Archivo Histórico José Vial Armstrong (1987b). Reprinted with permission. 
but their goal is to create a place-in the poetic sensefor an active and celebrative encounter with otherness, namely the local community and nature.

Besides, the subject of study that each travesía seeks to approach, is associated with disciplinary questions decided upon before the trip in Valparaiso, which are gradually developed and reformulated on the ground. This process points out that the travesía de Amereida as a project has a temporality that exceeds the period of the trip, including the time for planning, the time for execution, and the time for the architectural summary back in Valparaiso. These three chronological periods are essential for the iterative mapping practice based on freehand drawing, conducted during the travesías project.

\subsection{Pre-Travesía: Mapping to Be Situated}

The pre-travesia is a period of three to four weeks before the travesía focused on collectively map the territory between Valparaiso and other places of the continent that are proposed by the members of the studio. It is a process to explore and trace the networks of urbanization shaping the territories, drawing up the potential routes and the places to be covered during the journey (see Figure 7). Hence, the pre-travesía mapping is composed of the major elements of urbanization, such as the road infrastructure, geo-political boundaries, settlements, and the urban services which both enable an understanding of the large-scale territorial complexities and enable one to get to the destinations. This mapping process remains open to the situated experience, and the discoveries coming from the architectural observation and the poetic acts. Then, every studio of the School produces portable collage maps (in different scales and with digital and analogue data) to be carried within the travel-logs and to be enriched during the travesía.

\subsection{Travesía: Situated Mapping}

The travesía is a period of two or three weeks of situated practices in the continent. In this period, the mapping consists mainly of the making of freehand drawing in the travel-logs of students and teachers, which are shared to reflect and to co-design the architectural Work. During the travesia, the mapping process is deployed in two moments, during the trip and at the destination. First, during the trip, the group redraws maps of the territorial urbanization to corroborate and redefine the path that is underway. Besides this, they execute architectural observations 'in motion' in which the landscape is drawn

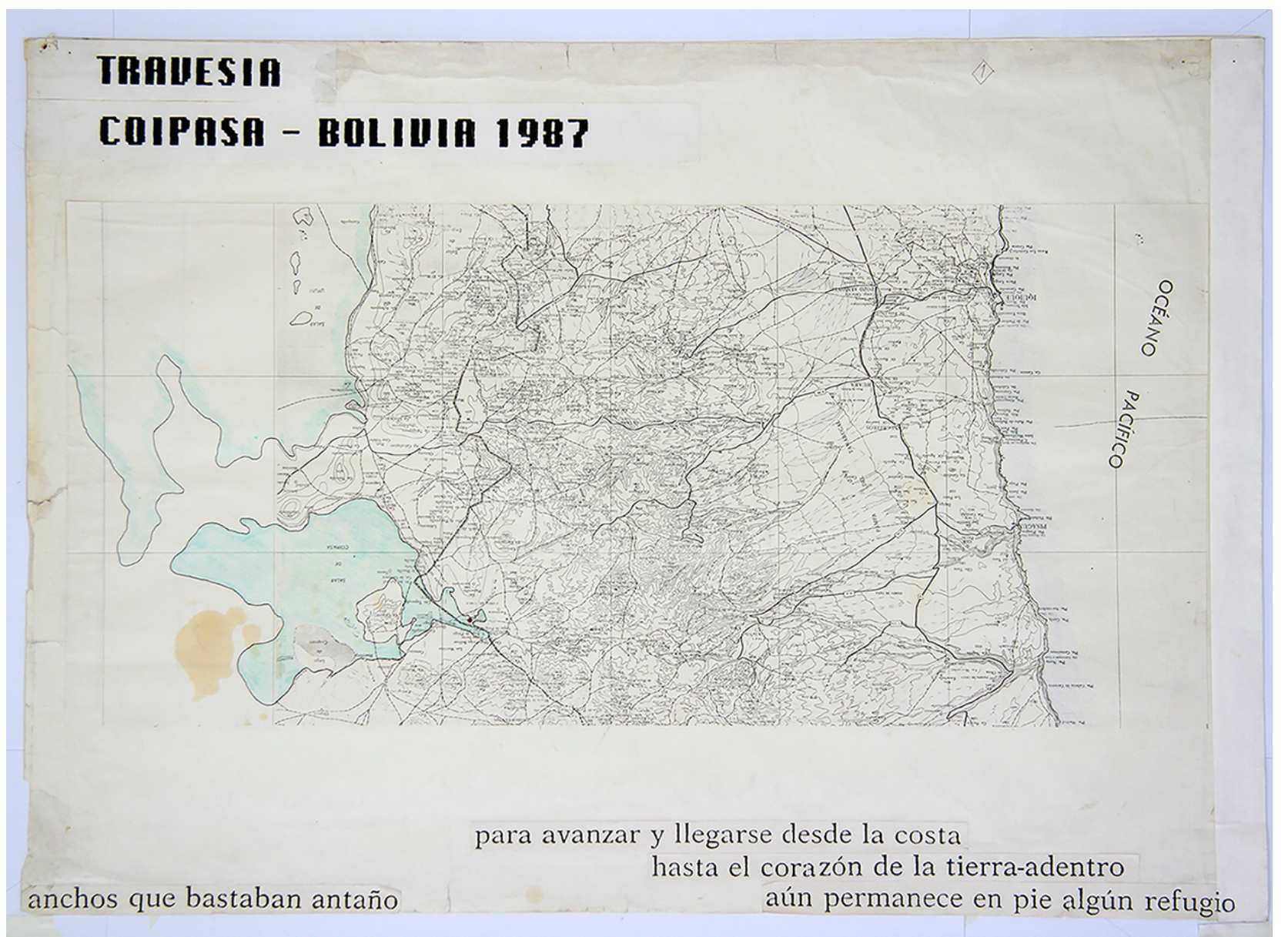

Figure 7. Mapping of the Altiplano region in Los Andes Mountain with fragments of the Amereida's poem. Pre-travesía of Salar de Coipasa, 1987, Bolivia. Source: Archivo Histórico José Vial Armstrong (1987a) Reprinted with permission. 
through the window of the bus and during the brief stops in different places across the continent (see Figure 8 top). This mapping might last more than six days when the destination point is far away from Valparaiso (e.g., the north of Brazil), or when there is no road (e.g., the Patagonian Fjords).

The second moment is at the destination. After the arrival, the group performs a study of the place and its surroundings through the making of architectural observations and cartographic schemes of the landscape (see Figure 8, bottom row). After defining the site for the work, together with the local community-if there is one-a more exhaustive morphological and topographic analysis is performed. Simultaneously, the design and construction of the project are developed, in which local materials and artisanal techniques are implemented. This whole process of describing, documenting, and designing is iterative because it requires constant reflection upon the drawings made during the trip and at the destination, to confront them with the preconceived ideas set in Valparaiso, and to iterate consideration of the real possibilities and resources for the Work.

\subsection{Post-Travesía: Mapping as Narrative}

The post-travesía is a period of one to two weeks after the travesia, in which the studios summarize their experience through a public exhibition that gives accounts of the trip, the Work, and the new knowledge unveiled by the travesía. This period is fundamental for the School of Valparaiso because each experience can be incorporated into the collective knowledge since the travesías de Amereida are considered a single project with hundreds of shared experiences.

Therefore, the large amount of material produced in the travel-logs of students and teachers-such as the architectural observations and the collective design drawings - is shared to present a common vision about the architectonic work executed and about the travelled extent. To summarize the travesía, the description of the project is usually illustrated through a series of schematic maps, such as those displayed in this sequence of freehand drawings (see Figure 9). Using schemes in different scales but in equal size, this sequence aim to describe: (1) the international path of this travesía following the

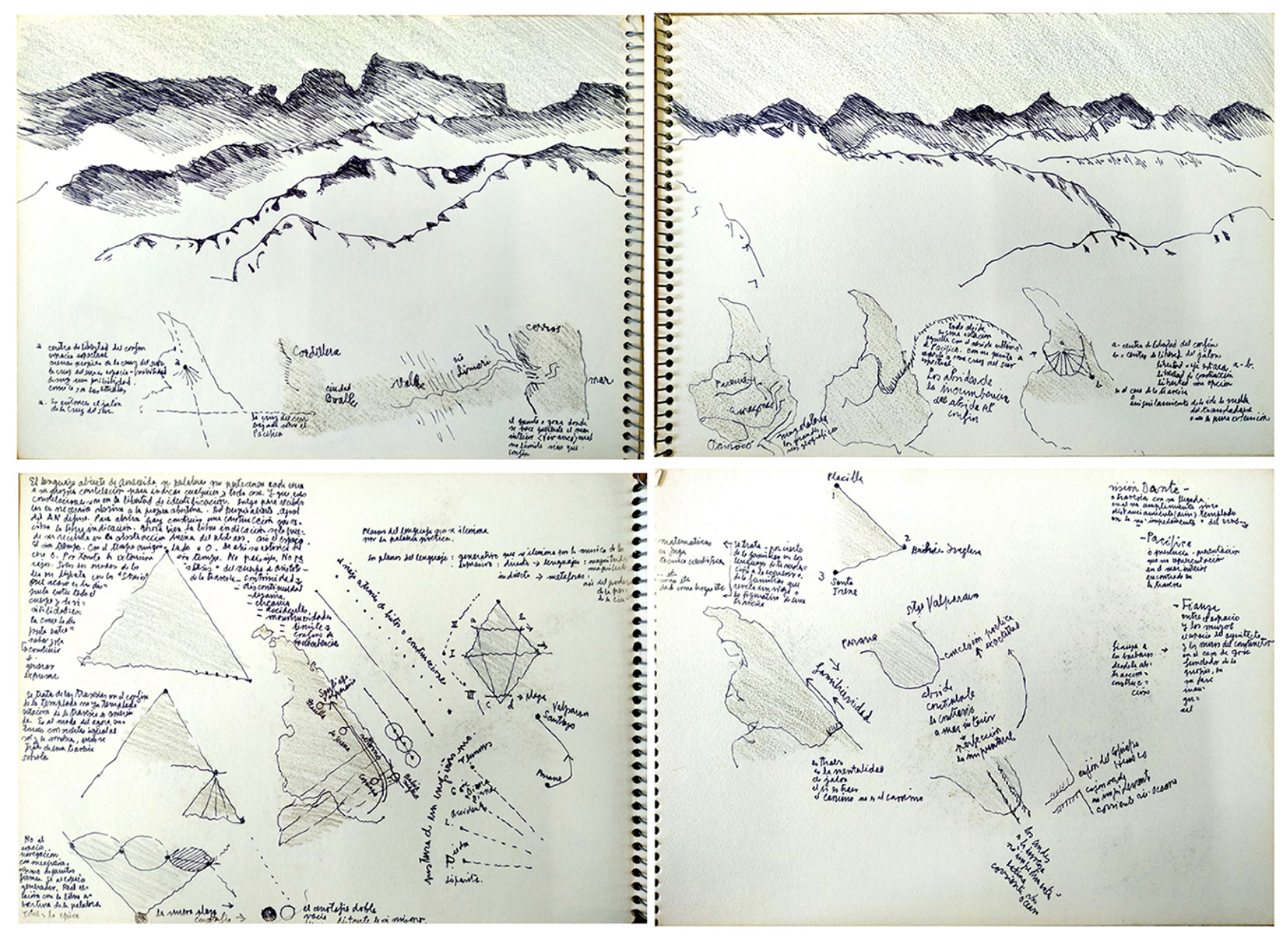

Figure 8. Travel-log of Alberto Cruz. Set of drawings in the Altiplano in Los Andes Mountain and schemes about the great rivers of South America and the site of the work in the travesía of San Andrés-Rosario, 1984, Argentina. Source: A. Cruz (1984). Reprinted with permission. 

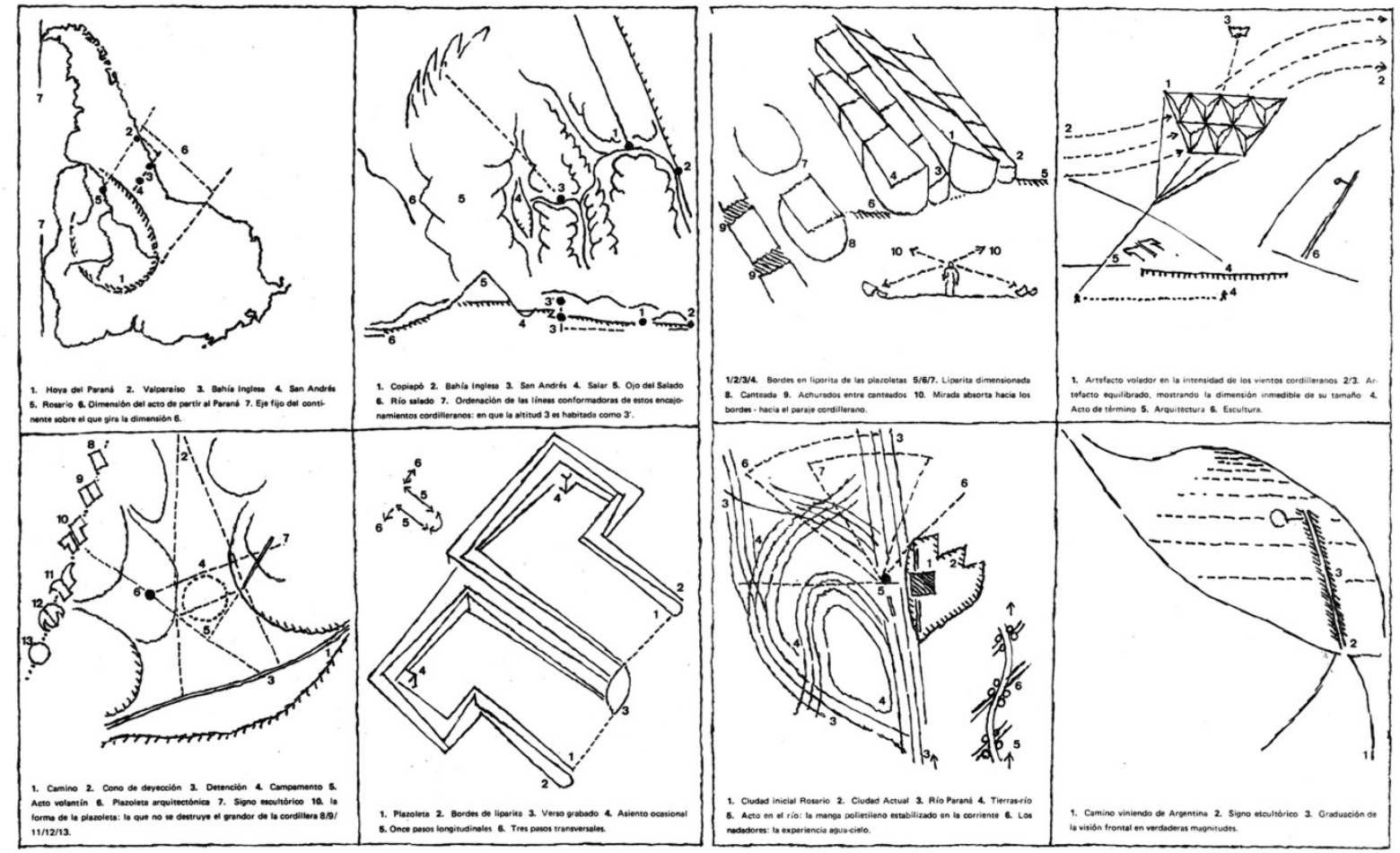

Figure 9. Sequence of maps describing the travesía of San Andrés-Rosario, 1984, Argentina. Source: Escuela de Arquitectura UCV (1991, pp. 184-185). No Copyright.

major hydrographic basin of South America; (2) the profiles of the territory surrounding the site of the work; (3) the layouts of roads and the camp; (4) the layout of the work traced on the ground; and (5) the isometrics details of the Work.

The mapping process made after the return to Valparaiso can be found in diverse exhibitions about the travesías until today. However, the most remarkable aspect of the schemes of the travesía of San Andrés, is the invention of the 'sequential frame,' in which the temporality and spatiality experienced are carefully represented in freehand drawings that shift from two to three spatial dimensions, and from the human to the continental scales. Then, the comments under the schemes highlight the relationship between the spatial intervention and the continental extent.

Thus, the iterative mapping practice permits to link and intersect the chronologies of the pre-travesía, the travesía and the post-travesía, with the ever-changing territorial realities, which is deeply attached to the situated experience of making the works in the place. This iterative and collective process to explore the documentation and the interpretation of urban and non-urban territories is understood as a palimpsestic mode to trace the territorial footprints of urbanization imprinted beyond the traditional city boundaries.

\section{Conclusion}

The School of Valparaiso-with more than 250 travesías performed in the South American continent-has been committed to unveiling the continent through their situated geo-poetic approach, is based on the fact that the travesías allow for the continual reinterpretation the territory beyond preconceived and conventional categories. This geo-poetic notion has permitted a critical regard of the historiography described since the Invention of America (O'Gorman, 2010/1958) in the 15th century, and the American extent has been a path to unveil the differences (lommi et al., 1967, p. 84) of realities shaping urban and non-urban 'territories,' as opposed to the concepts of sovereignty and power relations over the lands.

The geo-poetic approach of the School of Valparaiso, which is a radical alternative to the usual technocratic attitudes towards territories, might be part of a turn toward critical thinking and practices emerging within academia, which range from decolonial epistemologiesthat seek to bring into light the ever-changing territorial differences of territories which have been rendered virtually invisible by hegemonies inherited from colonization (Escobar, 2008; Mignolo, 2000; Mignolo \& Tlostanova, 2012; Mignolo \& Walsh, 2018)-to the exploration of new design practices committed to addressing these non-conventional issues in the field of design (Demos, 2016; Escobar, 2018; Javet, 2017).

Likewise, the geo-poetic mapping, envisaged as an exploratory and critical practice towards territories and urbanization, is an open field to radically rethink architecture and urbanism due to its engagement in direct experience such as situated hermeneutic mapping (Corner, 2014; Havik, 2014; Viganò, 2014, 2016). The latter performs descriptive and imaginative interpretations 


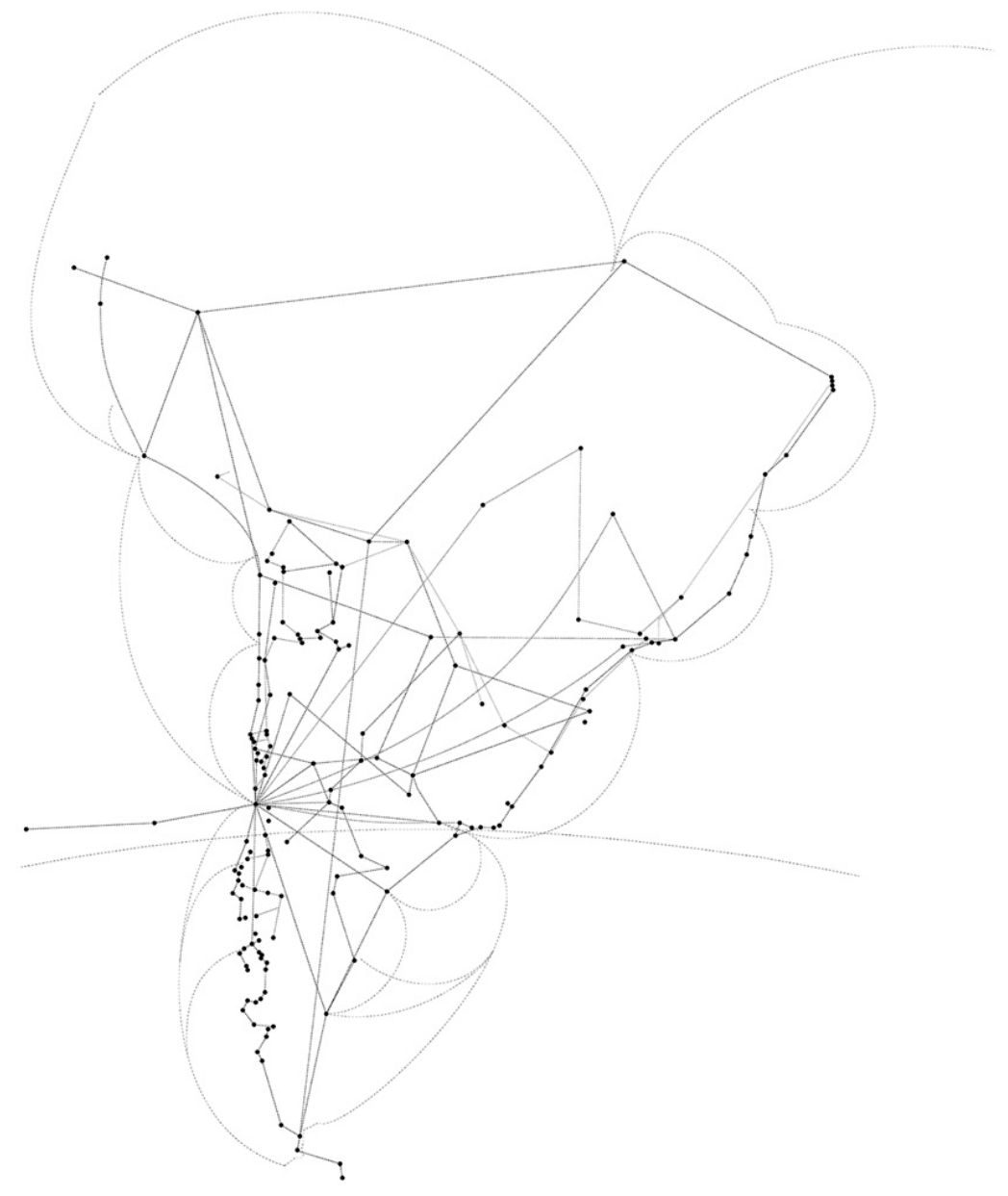

Figure 10. Shaping the South American extent through the routes performed by the travesías de Amereida. Map by the authors.

on multiple dimensions of territories, which are virtually impossible to grasp solely through the use of remote analytical devices, such as those advocated by landscape urbanism (Thompson, 2012).

Looking back to the whole ensemble of travesías de Amereida, we state that their geo-poetic orientation to unveil the visible and invisible meanings embedded in reality (Heidegger, 1971/2001; Merleau-Ponty, 1964/1968) has been the base to sustain these experiences for more than four decades (see Figure 10). For the school, the metaphor of the unknown leads them to keep the territories unveiled by the travesías as an extent open to be permanently re-visited, as a palimpsest that can be continuously re-read and re-drawn (Corboz, 1983).

Consequently, the geo-poetic practices performed during the travesia are not actions conducted to master the lands, but rather to unfold new insights into the everchanging transformations territories outside the cities. By incorporating design drawings and the building of Works into the geo-poetic mapping palimpsest, the travesía intends to restore the fundamental act of making (Ingold, 2013) as a means of engaging in broader reflection on the territories. Furthermore, the travesia's mapping and making are deeply embedded in the place and in the encounter with otherness. It is this which allows one to reinterpret situations and differences through a relational understanding beyond the conventional dichotomies of urbanization, such as rural/urban, public/private, country/city, or local/global.

Ultimately, the geo-poetic mapping palimpsest developed during the travesías, have been the medium to move from a passive-contemplation based on the analysis of data and the interpretation of reality, to an activecontemplation (Browne, Cáraves, \& Jolly, 2011), oriented to make situations from which new insights about territorial and urban questions can be drawn. This active engagement to search for knowledge of the openness is embodied in Amereida's geo-poetic statement "the road is not the road" (lommi et al., 1967, p. 189).

\section{Conflict of Interests}

The author declares no conflict of interests.

\section{References}

Archivo Histórico José Vial Armstrong. (1965). No Title. [Photoraphy]. Fondo AHACV, Valparaíso, Chile. 
Archivo Histórico José Vial Armstrong. (1987a). No Title. [Photoraphy]. Fondo AHACV, Valparaíso, Chile.

Archivo Histórico José Vial Armstrong. (1987b). TRA coi 87-Salar de Coipasa 3-30. [Photoraphy]. Fondo AHACV, Valparaíso, Chile.

Ashcroft, B., Griffiths, G., \& Tiffin, H. (2013). Post-colonial studies: The key concepts (2nd Ed.). New York, NY: Routledge.

Bélanger, P. (2017). Landscape infrastructure. New York, NY: Routledge.

Brenner, N. (Ed.). (2014). Implosions/explosions: Towards a study of planetary urbanization. Berlin: Jovis.

Brenner, N. (Ed.). (2016). Critique of urbanization: Selected essays. Basel: Birkhäuser.

Browne, E., Cáraves, P., \& Jolly, D. (2011). Alberto Cruz Covarrubias: La arquitectura como "extensión orientada que da cabida" [Alberto Cruz Covarrubias: Architecture as "oriented extent that accommodates"]. AOA: Asociación de Oficinas de Arquitectos, 2011(16), 24-47.

Buttazoni, O., Casanueva, M., Cruz, A., Díaz, C., lommi, G., Sánchez, J., \& Verchuaren, J. (1971). Para una Situación de América Latina en el Pacífico [For a Latin American situation in the Pacific]. In Fundamentos de la Escuela de Arquitectura, Universidad Católica de Valparaíso [Fundamentals of the School of Architecture, Universidad Católica de Valparaíso] (pp. 4-40). Santiago: Consejo de Rectores de las Universidades Chilenas.

Corboz, A. (1983). Le territoire comme palimpseste [The territory as palimpsest]. Diogène, 121, 14-35.

Corner, J. (2014). The landscape imagination: Collected essays of James Corner 1990-2010. New York, NY: Princeton Architectural Press.

Correa, F. (2016). Beyond the city: Resource extraction urbanism in South America. Austin, TX: University of Texas Press.

Cruz, A. (n.d.). Amereida [fragment]. Serie Correspondencia (5.15). Fondo Documental Alberto Cruz C., Fundación Alberto Cruz Covarrubias, Santiago, Chile.

Cruz, A. (1959). Improvisación del arquitecto Alberto Cruz [Improvisation of the architect Alberto Cruz]. Paper presented at the Primera Conferencia de Facultades Latinoamericanas de Arquitectura, Santiago, Chile.

Cruz, A. (1965). Bitácora Travesía Amereida [Travellog Travesía Amereida]. Serie Cuadernos (C.TR.-18). Fondo Documental Alberto Cruz C., Fundación Alberto Cruz Covarrubias, Santiago, Chile.

Cruz, A. (1982). Estudio acerca de la observación en arquitectura [Study about the architectural observation]. Viña del Mar: Taller de Investigaciones Gráficas, Escuela de Arquitectura UCV.

Cruz, A. (1984). No title. [Travel-log]. Serie Cuadernos (C.TR.-27). Fondo Documental Alberto Cruz C., Fundación Alberto Cruz Covarrubias, Santiago, Chile.

Cruz, A. (1995). De las relaciones entre estudiosos [On relations between scholars]. Viña del Mar: Taller de Investigaciones Gráficas, Escuela de Arquitectura UCV.
Cruz, F. (1993). Sobre la observación [About the observation]. Paper presented at the Seminario El Mundo del Croquis, Viña del Mar, Chile.

Demos, T. J. (2016). Decolonizing nature: Contemporary art and the politics of ecology. Berlin: Sternberg Press.

Elden, S. (2013). The birth of territory. Chicago, IL: University of Chicago Press.

Escobar, A. (2008). Territories of difference: Place, movements, life, redes. London and Durham, NC: Duke University Press.

Escobar, A. (2018). Designs for the pluriverse: Radical interdependence, autonomy, and the making of worlds. Durham, NC: Duke University Press.

Escuela de Arquitectura UCV. (1970). Para un punto de vista Latinoamericano del Océano Pacífico [Toward a Latin-American perspective on the Pacific Ocean]. Revista de Estudios Del Pacífico, 2, 7-27.

Escuela de Arquitectura UCV. (1972). Exposición 20 años Escuela de Arquitectura UCV [Exhibitions of the 20 years of the School of Architecture UCV]. Valparaiso: Taller de Investigaciones Gráficas, Escuela de Arquitectura UCV.

Escuela de Arquitectura UCV. (1991). Amereida, travesías 1984 a 1988 [Amereida, travesías 1984 to 1988]. Valparaiso: Taller de Investigaciones Gráficas, Escuela de Arquitectura UCV.

Escuela de Arquitectura UCV. (1996). Amereida en Barcelona [Amereida in Barcelona]. Viña del Mar: Taller de Investigaciones Gráficas, Escuela de Arquitectura UCV.

Eyquem, M. (1985). Acerca de la Cruz del Sur [About the Southern Cross]. In Diez separatas del libro no escrito: Sobre las crónicas de las proclamaciones de la travesía al "Mar Dulce" o desembocadura urbana de la hidrografía de América Latina [Ten sections of the unwritten book: On the chronicles of proclamations of the Travesía to the "Mar Dulce" or urban estuary of Latin America's hydrography]. (pp. 123-128). Valparaiso: Taller de Investigaciones Gráficas, Escuela de Arquitectura UCV.

Havik, K. (2014). Urban literacy: Reading and writing architecture. Rotterdam: Nai010 Publishers.

Heidegger, M. (2001). Thought, poetry language. New York, NY: Harper \& Row Publishers. (Original work published 1971)

Ibañez, D., \& Katsikis, N. (Eds.). (2014). Grounding metabolism [Special Issue]. New geographies, 2014(6), 2-10.

Ingold, T. (2013). Making: Anthropology, archaeology, art and architecture. Abingdon: Routledge.

Iommi, G. (1965). Oda a Kappa [Oda to Kappa]. Paris: Instituto de Arte UCV.

Iommi, G. (1982a). Eneida-Amereida. Viña del Mar: Taller de Investigaciones Gráficas, Escuela de Arquitectura UCV.

Iommi, G. (1982b). Hay que ser absolutamente moderno [One must be absolutely modern]. In 4 Talleres de 
América (pp. 69-85). Valparaiso: Taller de Investigaciones Gráficas, Escuela de Arquitectura UCV.

lommi, G. (1982c). Introducción al primer poema de Amereida [Introduction to the first poem of Amereida]. Valparaiso: Escuela de Arquitectura UCV.

lommi, G. (1983). América, Américas mías [America, my Americas]. Revista Atenea, 1983(447), 67-75.

lommi, G. (1984). El Pacífico es un mar erótico [The Pacific is an erotic sea]. In Dos conversaciones (p. 9). Viña del Mar: Taller de Investigaciones Gráficas, Escuela de Arquitectura UCV.

Iommi, G. (1999). Godo. Viña del Mar: Archivo Histórico José Vial Armstrong.

lommi, G., Cruz, A., Cruz, F., Girola, C., Boulting, J., Deguy, M., . . . Simons, E. (1967). Amereida. Santiago: Editorial Cooperativa Lambda, Colección Poesía.

lommi, G., Rodriguez, V., Emilfork, L., \& de Nordenflycht, A. (1972). Odas. Santiago: Ediciones Universitarias de Valparaíso.

lommi, G., Cruz, A., Cruz, F., Girola, C., Boulting, J., Deguy, M., .. . Simons, E. (1986). Amereida II. Viña del Mar: Taller de Investigaciones Gráficas UCV.

Javet, V. (2017). Landscape as geopolitics: Beyond colonial and capitalist states. Interviews with Pierre Bélanger and Lucy Lippard. Ground, 2017(40), 21-27. Retrieved from https://www.oala.ca/grounddetails/?issue $=33535$

Jolly, D. (2017). Arquitectura efímera [Ephemeral architecture]. Acto y Forma, 2(3), 12-19.

Kaika, M., \& Swyngedouw, E. (2014). Radical urban political-ecological imaginaries: Planetary urbanization and politicizing nature. Dèrive, 55(May), 15-20.

Merleau-Ponty, M. (1968). The visible and the invisible. Evanston, IL: Northwestern University Press. (Original work published 1964)
Mignolo, W. (2000). Local histories/global designs: Coloniality, subaltern knowledges, and border thinking. Princeton, NJ: Princeton University Press.

Mignolo, W., \& Tlostanova, M. (2012). Learning to unlearn: Decolonial reflections from Eurasia and the Americas. Columbus, $\mathrm{OH}$ : Serie Transoceanic Studies, Ohio State University Press.

Mignolo, W., \& Walsh, C. (2018). On decoloniality: Concepts, analytics, praxis. Durham, NC: Duke University Press.

O'Gorman, E. (2010). La invención de América [The invention of America]. Mexico City: Fondo de Cultura Económica. (Original work published 1958)

Raffestin, C. (2012). Space, territory, and territoriality. Environment and Planning D: Society and Space, 30(1), 121-141. https://doi.org/10.1068/d21311

Santos, M. (2017). The return to territory. In L. Melgaço \& C. Prouse (Eds.), Milton Santos: A pioneer in critical geography from the Global South (Vol. 11, pp. 25-32). Cham: Springer International Publishing. https://doi. org/10.1007/978-3-319-53826-6

Thompson, I. H. (2012). Ten tenets and six questions for landscape urbanism. Landscape Research, 37(1), 7-26. https://doi.org/10.1080/01426397.2011. 632081

UN-Habitat. (2016). Urbanization and development: Emerging futures. World cities report 2016. Nairobi: United Nations Human Settlements Programme.

Viganò, P. (2014). Territorialism. Cambridge, MA: Harvard University Graduate School of Design.

Viganò, P. (2016). The territories of urbanism: The project as knowledge producer. Lausanne: EPFL Press.

Waldheim, C. (2016). Landscape as urbanism: A general theory (1st Ed.). Princeton, NJ: Princeton University Press.

\section{About the Authors}

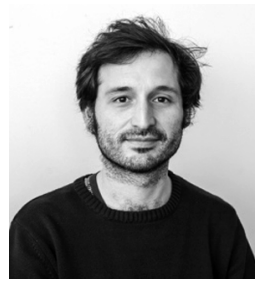

Álvaro Mercado is a Doctoral Researcher (Granted by ANID-Chile) of the LoUIsE-Laboratory at the Faculty of Architecture of Université libre de Bruxelles. His research explores the geo-poetic of design developed by the School of Valparaiso (1965-2020) as a critical approach to study the urbanization of South America. He is also an assistant professor at the Faculty of Architecture and Design of the PUC-Valparaiso, where he has conducted studios and research focused on the exploration of on-site design practices towards territories.

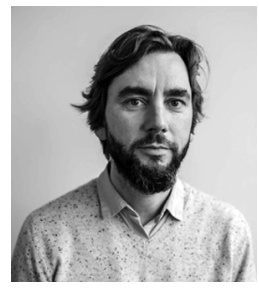

Geoffrey Grulois is Professor of Urbanism and Coordinator of LoUlsE-Laboratory at the Faculty of Architecture of Université libre de Bruxelles. His teaching and research explore the discipline of urbanism at the intersection of urbanization, human geography, metabolism, and ecologies. He is the co-coordinator of Metrolab. Brussels, a transdisciplinary laboratory for critical urban research (ERDF), and the academic coordinator of the Advanced Masters in transition urbanism at the ULB. He coedited UpCycle Barcelona: Cogenerative Design Strategies for a Sustainable Urban Metabolism (2015), Designing Territorial Metabolism: Barcelona, Brussels and Venice (2018), and Designing Brussels Ecosystems (2020). 